\title{
NELFA wt Allele
}

National Cancer Institute

\section{Source}

National Cancer Institute. NELFA wt Allele. NCI Thesaurus. Code C75439.

Human NELFA wild-type allele is located in the vicinity of $4 \mathrm{p} 16.3$ and is approximately 59 $\mathrm{kb}$ in length. This allele, which encodes negative elong ation factor A, plays a role in regulation of RNA polymerase II-dependent transcription. Mutations in this gene may be associated with Wolf-Hirschhorn syndrome. 